\title{
Soil nutrient levels define herbage yield but not root biomass in a multispecies grass-legume ley
}

\author{
Wen-Feng Cong ${ }^{\mathrm{a}, \mathrm{b}, *}$, Bent T. Christensen ${ }^{\mathrm{a}}$, Jørgen Eriksen ${ }^{\mathrm{a}}$ \\ ${ }^{a}$ Department of Agroecology, Aarhus University, Blichers Allé 20, 8830, Tjele, Denmark \\ ${ }^{\mathrm{b}}$ Department of Plant Nutrition, China Agricultural University, No. 2 Yuanmingyuan West Road, 100193, Beijing, China
}

\section{A R T I C L E I N F O}

\section{Keywords:}

Grass-legume mixtures

Long-term experiment

Nutrient availability

Nutrient source

Root-to-shoot ratio

\begin{abstract}
A B S T R A C T
The response of above- and below-ground biomass to soil nutrient availability is crucial for estimating belowground carbon input and predicting changes in soil carbon storage. However, the response is far from clear at plant community level, especially for grassland systems. Using a long-term field experiment initiated 123 years ago with varying soil nutrient levels (deficient, sub-optimal, optimal and over-optimal) established by use of two nutrient sources (animal manure or mineral fertiliser), we examined the effects of soil nutrient level and source on herbage yield and composition, root biomass and root-to-shoot (R/S) ratio of an unfertilised multispecies grass-legume ley. Increased nutrient levels enhanced herbage yield, but did not affect root biomass. The R/S ratio decreased from deficient to sub-optimal level, but remained constant from optimal to over-optimal level. Nutrient source did not influence herbage yield, root biomass or R/S ratio, but the legume proportion increased in soils previously receiving mineral fertiliser. The R/S ratio decreased with herbage yield, but did not vary with herbage composition. We conclude that soil nutrient level and herbage yield rather than nutrient source and herbage composition determine biomass allocation between aboveground and belowground in temperate grassland leys.
\end{abstract}

\section{Introduction}

The increase in atmospheric $\mathrm{CO}_{2}$ concentration and global food demand has stimulated interest in sequestering carbon (C) in the world's croplands to mitigate climate change and improve soil quality (IPCC, 2014; Lal, 2004). Simulation models, such as RothC (Coleman et al., 1997) and C-TOOL (Taghizadeh-Toosi et al., 2014), are often employed to evaluate soil $\mathrm{C}$ sequestration of various land uses and to derive management practices with soil $\mathrm{C}$ sequestration potentials. However, most models simulate plant $\mathrm{C}$ input to soils by assuming that a fixed fraction of net primary production is allocated to below-ground plant components (e.g. Bolinder et al., 2007), without considering the impact of environmental factors such as nutrient availability (Poorter et al., 2012). This allometric approach has been questioned in recent studies showing that a fixed root-to-shoot $(\mathrm{R} / \mathrm{S})$ ratio may over-estimate belowground $\mathrm{C}$ input at higher nitrogen $(\mathrm{N})$ fertiliser levels (Taghizadeh-Toosi et al., 2016) and lead to large uncertainty in estimating plant $C$ inputs to soils (Keel et al., 2017). Hence, quantifying the response of above- and below-ground biomass allocation to nutrient availability is crucial for improved estimates of plant $\mathrm{C}$ inputs to soils and predicting trends in soil $\mathrm{C}$ storage.
The concept known as 'functional equilibrium' has remained a cornerstone in estimating belowground biomass allocation (Iwasa and Roughgarden, 1984). This concept predicts that plants will allocate biomass to enhance the capture of the most limiting factor. When soil nutrient availability becomes the limiting factor, plants will allocate a larger fraction of the produced biomass to the root system to exploit a larger soil volume for nutrients, thus leading to higher $\mathrm{R} / \mathrm{S}$ ratio. However, the concept relies mainly on studies at individual plant level (Field, 1991). In multispecies plant communities, competition-derived changes in species composition may compensate for shortage of available plant nutrients and thus eliminate major changes in belowground biomass allocation (Friedlingstein et al., 1999). Currently it remains unclear to which extent changes in species composition compensate for changes in biomass allocation in multispecies grassland subject to nutrient stress.

Grassland ecosystems store up to $30 \%$ of the world's soil C and thus play a significant role in the global C cycle (Anderson, 1991). Most production grasslands rely on two functional groups (grasses and legumes) with different $\mathrm{R} / \mathrm{S}$ ratios and responses to nutrient availability (Reich et al., 2003; Xia and Wan, 2008). It is recognized that nutrient availability shapes the composition, diversity and productivity of

\footnotetext{
* Corresponding author at: Department of Agroecology, Aarhus University, Blichers Allé 20, 8830, Tjele, Denmark.

E-mail address: wenfeng.cong@cau.edu.cn (W.-F. Cong).
} 
grasslands (Grime, 2002; Tilman, 1988). However, it remains obscure how changes in aboveground biomass production driven by nutrient availability influence root biomass production in multispecies systems and thus the R/S ratio of the whole plant community.

Previous meta-analyses attempted to quantify the effects of environmental factors on biomass allocation (e.g. Poorter and Nagel, 2000). However, this approach is questionable because comparisons based on experiments discriminating only between 'high' and 'low' levels of one given environmental factor do not capture how biomass allocation responds to a wider environmental gradient (De Groot et al., 2001; Poorter et al., 2012) and neglect the effects of concomitant variations in other environmental factors. Thereby, these studies may not reflect the actual response of biomass allocation to the focal environmental factor. This drawback could be overcome by utilising existing long-term fertiliser experiments. On the one hand, long-term different fertiliser histories provide a wider range of soil nutrient levels. On the other hand, long-term experiments generally have a well-documented management history, avoiding potential effects confounded by other environmental factors.

This study aims to explore the effects of soil nutrient availability on above- and below-ground biomass allocation of multispecies production grasslands using a 120-year-old Askov Long-Term Experiment (AskovLTE). The Askov-LTE includes replicate plots with different rates of nutrients applied in either animal manure (AM) or mineral fertiliser (NPK) and grows a four-course crop rotation, including an unfertilised six-species grass-legume ley. Specifically, we examine how soil nutrient levels (deficient, sub-optimal, optimal and over-optimal) and nutrient sources (animal manure and mineral fertiliser) influence herbage yield and composition, root biomass and $\mathrm{R} / \mathrm{S}$ ratio of the unfertilised multispecies grass-legume ley. We hypothesized that nutrient level affects herbage yield more than root biomass leading to variations in R/S ratios, and that the nutrient source alters herbage composition by increasing grass proportion in plots previously receiving animal manure due to mineralization of residual manure N (Suarez-Tapia et al., 2018).

\section{Materials and methods}

\subsection{The askov long-term experiment (askov-LTE)}

The Askov-LTE was initiated in 1894 at the Lermarken site, Askov Experimental Station, Denmark $\left(55^{\circ} 28^{\prime} \mathrm{N}, 09^{\circ} 07^{\prime} \mathrm{E}\right)$. The soil is a light sandy loam ( $10 \%$ clay, $11 \%$ silt, $38 \%$ fine sand, $39 \%$ coarse sand, $2 \%$ organic matter) and classified as a Typical Hapludalf (USDA Soil Taxonomy). The soil is limed every four to five years to maintain topsoil $\mathrm{pH}$ between 5.5 and 6.5. Annual mean precipitation and potential evapotranspiration are 862 and $543 \mathrm{~mm}$, respectively, and annual mean temperature $7.7^{\circ} \mathrm{C}(1961-1990)$.

The Askov-LTE includes four separate fields (termed B2-, B3-, B4-, and B5-field) and grows a four-course rotation of winter wheat, silage maize (root crops until 2006), and spring barley undersown a six-species grass-legume ley. The ley is kept unfertilised and used for cutting in the subsequent production year. The four crops rotate across the four fields whereby a given field grows only one crop a given year. The ley includes three legumes (Medicago sativa L., lucerne; Trifolium hybridum L., alsike clover; Lotus corniculatus L., birdsfoot trifoil) and three grasses (Lolium perenne L., ryegrass; Festuca pratensis Huds., fescue; Phleum pratense L., timothy) with seeding rates of $10,3,3,5,5$, and $2 \mathrm{~kg} \mathrm{ha}^{-1}$, respectively.

The main fertiliser treatments are different rates $\left(0,1 / 2,1,1 \frac{1}{2}\right.$ times the standard rate for a given crop; grass-legume ley remains unfertilised) of nitrogen (total N), phosphorus (P) and potassium (K) applied either in mineral fertiliser (NPK) or in animal manure (AM; since 1973 cattle slurry with 5\% dry matter and approx. $60 \%$ of its total-N present as ammoniacal-N). Table 1 shows the quantity of nutrients added in 1 NPK and $1 \mathrm{AM}$ and the distribution across the crops. Christensen et al. (2006) provides further details on the Askov-LTE.
Table 1

Fertiliser history of the Askov LTE. The rate $\left(\mathrm{kg} \mathrm{ha}^{-1} \mathrm{yr}^{-1}\right)$ of total nitrogen (N), phosphorus (P) and potassium (K) added in $1 \mathrm{~A} \mathrm{M}$ (animal manure) and 1 NPK (mineral fertiliser) from 1973 to 2016.

\begin{tabular}{llccc}
\hline \multirow{2}{*}{ Period } & Crop & $\mathrm{kg} \mathrm{ha}^{-1} \mathrm{yr}^{-1}$ in $1 \mathrm{~A} \mathrm{M}^{\mathrm{a}}$ and $1 \mathrm{NPK}$ & \\
\cline { 3 - 5 } & & Total-N & $\mathrm{P}$ & $\mathrm{K}$ \\
\hline \multirow{2}{*}{$1973-2005$} & Winter wheat & 100 & 19 & 88 \\
& Root crops & 225 & 44 & 196 \\
& Spring barley & 75 & 14 & 65 \\
& Grass-legume ley & 0 & 0 & 0 \\
& Mean of rotation & 100 & 19 & 87 \\
\multirow{2}{*}{$2006-2016$} & Winter wheat & 150 & 30 & 120 \\
& Silage maize & 150 & 30 & 120 \\
& Spring barley & 100 & 20 & 80 \\
& Grass-legume ley & 0 & 0 & 0 \\
& Mean of rotation & 100 & 20 & 80 \\
\hline
\end{tabular}

a 1 AM typically corresponds to the addition of $25 \mathrm{t}$ cattle slurry (fresh weight) $\mathrm{ha}^{-1}$.

The current study was in the B5-field employing three randomly selected replicates of seven nutrient treatments $\left(0,1 / 2 \mathrm{NPK}, 1 \mathrm{NPK}, 1 \frac{1}{2}\right.$ NPK (only two replicates present), $1 / 2 \mathrm{AM}, 1 \mathrm{~A} \mathrm{M}$ and $1 \frac{1}{2} \mathrm{AM}$ ) providing a total of 20 plots. The treated plot is $11.7 \times 9.4 \mathrm{~m}\left(110 \mathrm{~m}^{2}\right)$, while the harvest plot is $7.3 \times 5 \mathrm{~m}\left(36 \mathrm{~m}^{2}\right)$. Previous work showed a small within-field variation in soil physical properties (e.g. soil texture) between plots in the B5-field (Peltre et al., 2016). Spring barley planted on 23 March 2016 was undersown with the grass-legume mixture. Barley harvest was on 16 August 2016 with straw removed from the field and the emerging ley was cut on 14 September 2016. In the production year 2017, the ley was not fertilised. In other words, the ley grew in soils with different fertiliser histories. The total precipitation and mean temperature during production periods (April to August) in 2017 were $394 \mathrm{~mm}$ and $12.8^{\circ} \mathrm{C}$, respectively. The climatic data of this year fell within the normal range of years since 2001 (Fig. S1).

\subsection{Soil sampling and chemical properties}

On 27 April 2017, 16 cores ( $2 \mathrm{~cm}$ inner diameter) were taken to a depth of $20 \mathrm{~cm}$ from the central area $\left(36 \mathrm{~m}^{2}\right)$ of each replicate plot. The soil cores were bulked, broken apart and well mixed. The subsamples were taken and large visible roots removed. Air-dry subsamples were sieved to $<2 \mathrm{~mm}$, and then dried at $40{ }^{\circ} \mathrm{C}$ until constant weight. Subsamples were ball milled and analysed for $\mathrm{C}$ and $\mathrm{N}$ concentrations by high-temperature dry combustion using an elemental analyser (vario MAX, Elementar, Germany). Soil pH was determined in $0.01 \mathrm{M} \mathrm{CaCl}_{2}$ $(1: 2.5 \mathrm{w} / \mathrm{v})$. Plant-available $\mathrm{P}$ (Olsen-P) was determined by extracting $1 \mathrm{~g}$ of soil with $20 \mathrm{ml}$ of $0.5 \mathrm{M} \mathrm{NaHCO}_{3}$ at $\mathrm{pH} 8.5$ for $0.5 \mathrm{~h}$. Plantavailable $\mathrm{K}$ was determined by extracting $5 \mathrm{~g}$ of soil with $50 \mathrm{ml}$ of $0.5 \mathrm{M}$ $\mathrm{NH}_{4} \mathrm{OAc}$ for $0.5 \mathrm{~h}$.

\subsection{Herbage yield and botanical composition}

A plot harvester (Haldrup C-85, Denmark) was used to cut the herbage $(7 \mathrm{~cm}$ stubble height) and record the fresh weight of herbage from each plot. The first cut was in mid-June (13 June 2017) and the second cut in late August (28 August 2017). For both cuts, the botanical composition of the herbage was determined by separating a $300 \mathrm{~g}$ subsample into grasses, legumes and weeds. Another $500 \mathrm{~g}$ subsample was dried at $80^{\circ} \mathrm{C}$ for two days to determine herbage dry matter (DM) content.

\subsection{Standing root biomass}

Standing root biomass was quantified using the auger method (do Rosário et al., 2000). Previous work showed that root biomass of grass- 
legume ley was substantially higher on rows than between rows (Cong et al., 2017) wherefore we quantified root biomass separately for onrow areas and between-row areas. Then whole-plot root biomass was the weighted sum of root biomass in the two areas. The row distance of grass-legume ley was $12 \mathrm{~cm}$, dividing the plot area into stripes each comprising $6 \mathrm{~cm}$-wide on-row area and $6 \mathrm{~cm}$-wide between-row area. Six random cores were taken in the on-row area and another three in the between-row area to account for the higher variation in the on-row area (Cong et al., 2017). In total, we collected 180 cores (20 plots $\times 9$ cores).

The soil cores ( $5.5 \mathrm{~cm}$ inner-diameter) taken to $20 \mathrm{~cm}$ depth shortly after the second harvest in late August were stored in plastic bags, transferred to the laboratory, and washed with tap-water immediately. Soil was removed by washing the roots on a $425-\mu \mathrm{m}$ sieve and by separating the roots from soil particles $>425 \mu \mathrm{m}$ (e.g. sand) by repeated decantation from a container onto the sieve. During the washing process, extraneous organic materials were carefully removed. Roots were dried at $60^{\circ} \mathrm{C}$ for $48 \mathrm{~h}$, weighed and then measured by loss-on-ignition at $550{ }^{\circ} \mathrm{C}$ in a furnace for $6 \mathrm{~h}$. The residue was weighed and the root biomass calculated on an ash-free basis.

\subsection{Data analyses}

One-way analysis of variance (ANOVA) was employed to analyse the effect of fertiliser history on soil chemical properties, herbage yield, botanical composition, root biomass and $\mathrm{R} / \mathrm{S}$ ratio. Differences between treatments were tested using Tukey's post hoc test. In certain cases, twoway ANOVA was further conducted to explore the effects of nutrient source (AM vs. NPK) and rate (1/2,1 and 11/2) using Type III sums of squares to account for the unbalanced design due to lack of one replicate in the $1 \frac{1 / 2}{2}$ NPK treatment.

Simple linear regressions were used to analyse the responses of root biomass and $\mathrm{R} / \mathrm{S}$ ratio to plant parameters and soil chemical properties. In certain cases, the broken-stick model was employed using the segmented function in the segmented package in R (R Core Team, 2013). The significance of the change point (i.e. the threshold value) was assessed using the davies.test implemented in this package. The resulting model followed:

$y=\beta_{0}+\beta_{1}(x)+\beta_{2}(x-c)^{+}+e$

where $y$ is the dependent variable; $x$ is the independent variable; $c$ is the change point; ${ }^{+}$indicates that this part is kept in the equation only when $x>c$, and $e$ is the residual error (Toms and Lesperance, 2003).

Data were log transformed when necessary for statistical analysis to meet the assumptions of normality and heterogeneity. All analyses were performed in the R software version 3.4.1.

\section{Results}

\subsection{Soil chemical properties}

Soil C concentration differed between soils with fertiliser history $(P<0.001$, Table 2$)$. The soil with the $1 \frac{1 / 2}{2}$ AM treatment held significantly more $C$ than soils exposed to the $1 / 2$ AM, $1 / 2$ NPK and unfertilised (0) treatments. The soils treated with $1 \mathrm{~A} \mathrm{M}$ and $1 \mathrm{NPK}$ also had higher soil C concentration than unfertilised soil. The $1 / 2$ AM and $1 / 2$ NPK treatments tended to increase soil C concentration compared to the unfertilised treatment, but differences were not statistically significant. A similar pattern was observed for soil $\mathrm{N}$ concentration $(P<0.001)$.

Both plant-available $\mathrm{P}$ and $\mathrm{K}$ varied considerably with fertiliser history (Olsen-P: $P<0.001$; $\mathrm{NH}_{4} \mathrm{OAc}-\mathrm{K}: P<0.001$, Table 2). The $1 \frac{1}{2}$ NPK treatment had the highest concentrations of available $\mathrm{P}$ and $\mathrm{K}$ among all treatments, while the unfertilised treatment had the lowest. Available $\mathrm{P}$ as well as $\mathrm{K}$ increased with fertiliser rates (from $1 / 2$ to $1 \frac{1 / 2}{2}$ ), but with a more distinct increase in plots that had received NPK than AM. Neither available P nor available K differed between the treatments $1 / 2 \mathrm{AM}$ and $1 / 2 \mathrm{NPK}$. Soil $\mathrm{pH}$ ranged from 6.0 to 6.7 across treatments but did not differ significantly $(P=0.091$, Table 2$)$.

\subsection{Herbage yield and composition}

Plots with a fertiliser history of AM or NPK produced higher herbage yields than unfertilised plots $(P<0.001$, Fig. 1a). Irrespective of fertiliser source (AM or NPK), plots with 1 and $1 \frac{1 / 2}{2}$ times standard fertiliser rate produced significant higher yield than those with $1 / 2$ time standard rate. The same pattern was observed in both cuts. The herbage yield averaged across the previous 11 growing seasons (1973-2013) was also higher in plots with a history of AM or NPK than in unfertilised plots $(P<0.001$, Fig. 1b). Furthermore, herbage yield increased from $1 \mathrm{~A} \mathrm{M}$ to $1 \frac{1 / 2}{2} \mathrm{AM}$.

Averaged across all treatments, the herbage yield in 2017 was $2.6 \mathrm{t}$ $\mathrm{ha}^{-1}$ higher than the average yield for 1973-2013, the largest increase occurring in the $1 \mathrm{NPK}$ and $1 \frac{1 / 2}{2}$ NPK treatments (Fig. 1a, b). When examining herbage yield for individual years, we found that yields tended to first increase and then stabilise over years (Fig. S1b). Moreover, we observed that the 2017 yield response to fertiliser history was similar to that in 2001 and 2005 with similar precipitation and temperature.

Legumes gave higher annual herbage yield than grasses regardless of fertiliser history (Fig. 2a). Moreover, the yield of grass as well as legume differed between plots with different fertiliser histories (Grass: $P<0.001$; Legume: $P<0.001$ ). Grass yield increased with previous AM rate but not with NPK rate. Legume yields increased more with rate of NPK than with rate of AM. Consequently, the legume proportion in herbage yield differed between soils with different fertiliser histories, being significantly higher for 1 NPK than for all levels of AM $(P=$ 0.008 , Fig. 2b). In addition, soils with $1 \frac{1}{2}$ NPK had higher legume proportion than the unfertilised soil. Weeds accounted for only $0.1-1.3$

Table 2

Chemical properties ( $\mathrm{pH}$, soil $\mathrm{C}$ and $\mathrm{N}$ concentration, plant-available $\mathrm{P}$ and $\mathrm{K}$ ) of soils with different fertiliser histories.

\begin{tabular}{|c|c|c|c|c|c|}
\hline Fertiliser history & Soil C ( $\mathrm{g} \mathrm{kg}^{-1}$ soil) & Soil N ( $\mathrm{g} \mathrm{kg}^{-1}$ soil) & Available P (mg kg ${ }^{-1}$ soil) & Available $\mathrm{K}$ (mg kg ${ }^{-1}$ soil) & $\mathrm{pH}(/)$ \\
\hline 0 & $9.5(0.5) c$ & $0.87(0.04) c$ & $3.7(1.2) \mathrm{d}$ & $23.7(3.3) \mathrm{f}$ & $6.7(0.0)$ \\
\hline $1 / 2 \mathrm{NPK}$ & $10.7(0.5) b c$ & $1.00(0.03) \mathrm{bc}$ & $6.7(0.3) \mathrm{cd}$ & $38.0(2.3) \mathrm{ef}$ & $6.0(0.2)$ \\
\hline $1 \mathrm{NPK}$ & $11.8(0.4) \mathrm{ab}$ & $1.04(0.05) \mathrm{b}$ & $19.3(2.0) \mathrm{b}$ & $85.0(6.2) \mathrm{c}$ & $6.1(0.1)$ \\
\hline $1 \frac{1}{2} \mathrm{NPK}$ & $11.5(0.7) \mathrm{abc}$ & $1.08(0.04) \mathrm{abc}$ & $33.5(1.5) \mathrm{a}$ & $138.0(2.0) \mathrm{a}$ & $6.1(0.3)$ \\
\hline $1 / 2 \mathrm{AM}$ & $11.5(0.2) \mathrm{b}$ & $1.09(0.03) \mathrm{b}$ & $5.3(0.3) \mathrm{d}$ & $42.3(0.7) \mathrm{e}$ & $6.4(0.1)$ \\
\hline $1 \mathrm{AM}$ & $12.1(0.3) a b$ & $1.12(0.04) \mathrm{ab}$ & $10.7(0.9) \mathrm{c}$ & $65.3(3.7) \mathrm{d}$ & $6.3(0.2)$ \\
\hline $11 / 2 \mathrm{AM}$ & $13.4(0.4) \mathrm{a}$ & $1.24(0.06) \mathrm{a}$ & $20.7(0.3) \mathrm{b}$ & $111.3(4.4) b$ & $6.5(0.2)$ \\
\hline
\end{tabular}

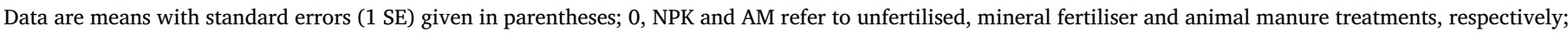

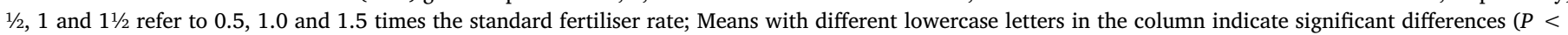
0.05) between fertiliser treatments using Tukey's post hoc test. 


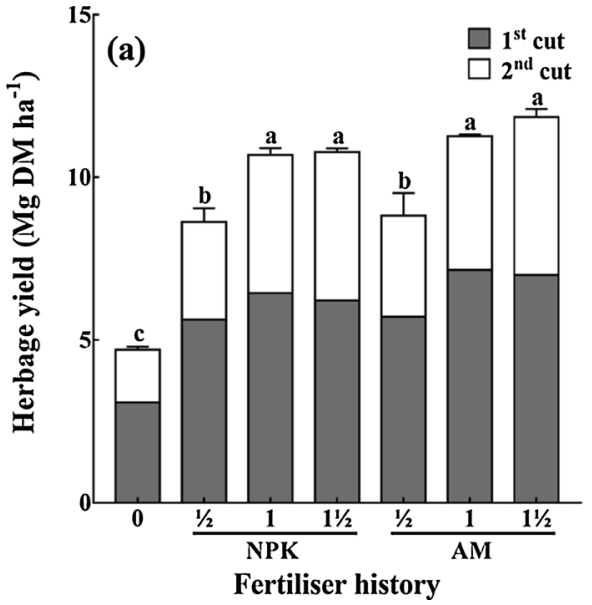

(b)

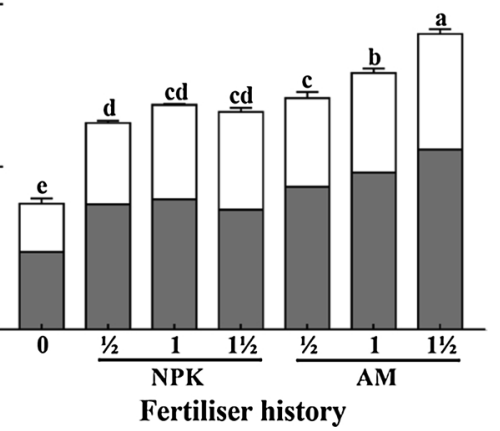

Fig. 1. Annual herbage yield (a, in 2017; b, averaged across 11 seasons from 1973 to 2013) of grass-legume leys grown in soils with different fertiliser histories. Filled and open columns represent mean herbage yield from replicated plots $(n=2$ for $1 \frac{1}{2}$ NPK, $n=3$ for the other treatments) at the $1^{\text {st }}$ cut and $2^{\text {nd }}$ cut, respectively. The error bars refer to $\pm 1 \mathrm{SE}$ of annual herbage yield. Columns with different lowercase letters indicate significant differences $(P<0.05)$ between fertiliser treatments using Tukey's post hoc test. Abbreviations for fertiliser treatments refer to Table 2 .
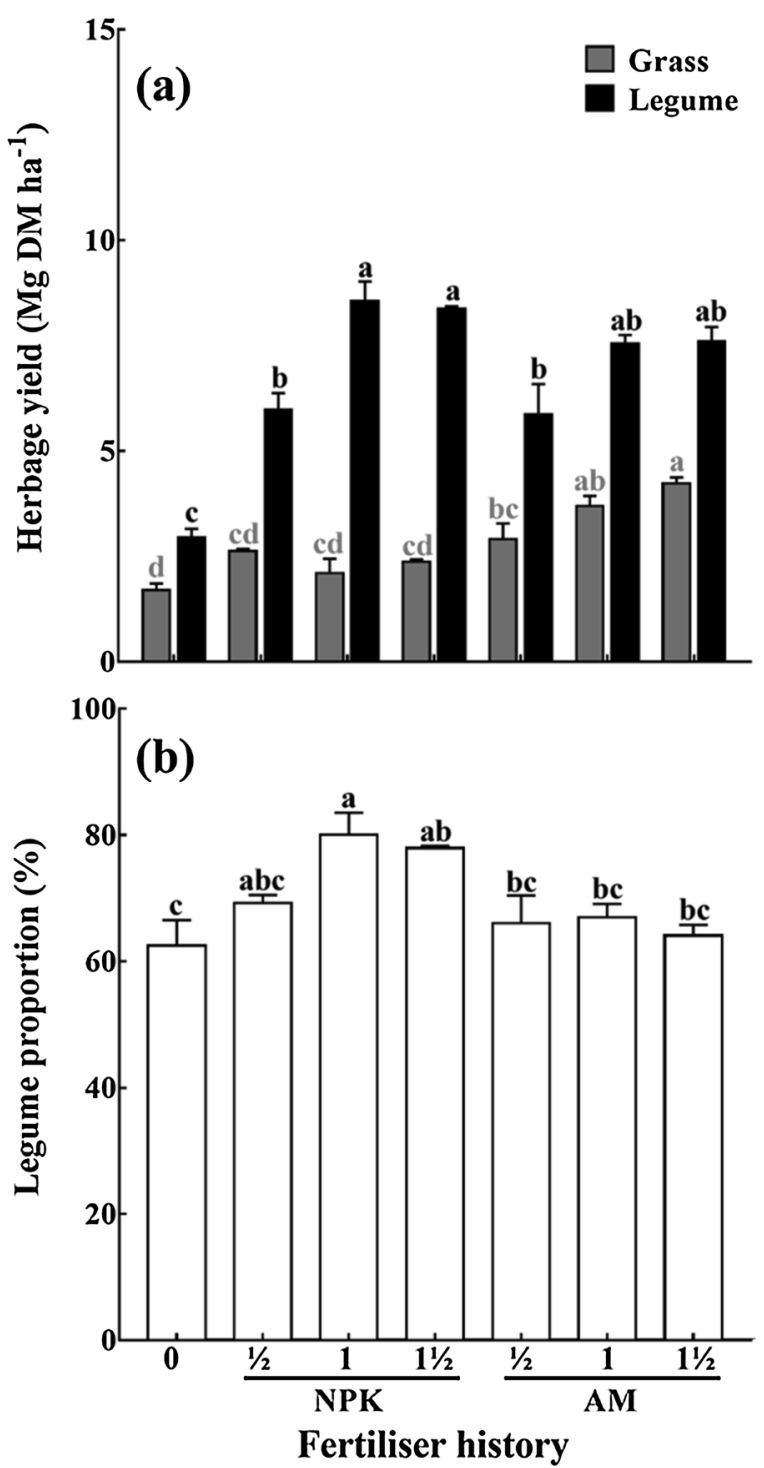

Fig. 2. Herbage composition (a, grass and legume yield; b, legume proportion) of grass-legume leys grown in soils with different fertiliser histories. Columns with error bars indicate means \pm 1 SE $\left(n=2\right.$ for $1 \frac{11}{2}$ NPK, $n=3$ for the other treatments). Columns with different lowercase letters indicate significant differences $(P<0.05)$ in grass or legume yield (Panel a), or legume proportion (Panel b) between fertiliser treatments using Tukey's post hoc test. Abbreviations for fertiliser treatments refer to Table 2.
$\%$ of total herbage yield and did not vary with fertiliser history.

\subsection{Root biomass}

Whole-plot root biomass (on an ash-free basis) at top $20 \mathrm{~cm}$ soil depth ranged from 2.99 to $3.77 \mathrm{Mg} \mathrm{DM} \mathrm{ha}{ }^{-1}$, but did not differ between plots with different fertiliser histories ( $P=0.637$, Fig. 3a). The ash fraction averaged $13.6 \%$ of the harvested DM across all plots and did not differ between treatments $(P=0.243)$. There was no effect of fertiliser history on root biomass neither on-rows nor between-rows (On-rows: $P=0.733$; Between-rows: $P=0.111$; Fig. $3 b$ ).

\subsection{Root-to-shoot ratio}

The root-to-shoot (R/S) ratio ranged from 0.32 to 0.93 (Fig. 4), with significantly lower ratios in plots with a fertiliser history of AM or NPK than in unfertilised plots $(P<0.001$ based on one-way ANOVA of logtransformed data). Excluding unfertilised plots, we conducted a twoway ANOVA to investigate the effects of fertiliser source (AM vs. NPK) and rate $\left(1 / 2,1\right.$ and $\left.1 \frac{1}{2}\right)$ on $R / S$ ratio. Results showed that the $R / S$ ratio did not differ between plots previously receiving AM and NPK $(P=$ 0.892), whereas the R/S ratio was lower in plots with 1 and $1 \frac{1 / 2}{2}$ time standard fertiliser rate than in plots with $1 / 2$ time fertiliser rate $(P=$ 0.010).

\subsection{Responses of root biomass and $R / S$ ratio to plant and soil parameters}

We applied linear regressions to examine if root biomass and R/S ratio related to herbage yield, composition and soil nutrient availability. Root biomass was not related to herbage yield that ranged from 4.5 to $12.1 \mathrm{Mg} \mathrm{DM} \mathrm{ha}^{-1}$ (Fig. 5a), whereas R/S ratio decreased linearly with increasing herbage yield $\left(r^{2}=0.890, P<0.001\right.$, Fig. $\left.5 c\right)$. Neither root biomass nor R/S ratio related to the legume proportion of herbage yield (Fig. 5b, d).

Root biomass did not respond to plant-available $\mathrm{P}$ or $\mathrm{K}$ in soil (Fig. 6a, b). In contrast, root-to-shoot ratio decreased linearly at low concentrations of plant-available $\mathrm{P}$ and $\mathrm{K}$, but stabilised at higher concentrations (Fig. 6c, d). A broken-stick model was able to identify threshold values of $8.75 \mathrm{mg} \mathrm{kg}^{-1}$ soil for Olsen-P and $48.7 \mathrm{mg} \mathrm{kg}^{-1}$ soil for $\mathrm{NH}_{4} \mathrm{OAc}-\mathrm{K}$. The Davies' test for a change in the slope was highly significant $\left(P=0.004\right.$ for Olsen-P and $P<0.001$ for $\left.\mathrm{NH}_{4} \mathrm{OAc}-\mathrm{K}\right)$. The resulting linear regression equations were:

$\mathrm{R} / \mathrm{S}$ ratio $=0.933-0.074$ Olsen-P +0.074 (Olsen-P-8.75) ${ }^{+}\left(r^{2}=0.702\right.$, $P<0.001)$

$\mathrm{R} / \mathrm{S}$ ratio $=1.150-0.017 \mathrm{NH}_{4} \mathrm{OAc}-\mathrm{K}+0.017\left(\mathrm{NH}_{4} \mathrm{OAc}-\mathrm{K}-48.7\right)^{+}$ $\left(r^{2}=0.816, P<0.001\right)$ 

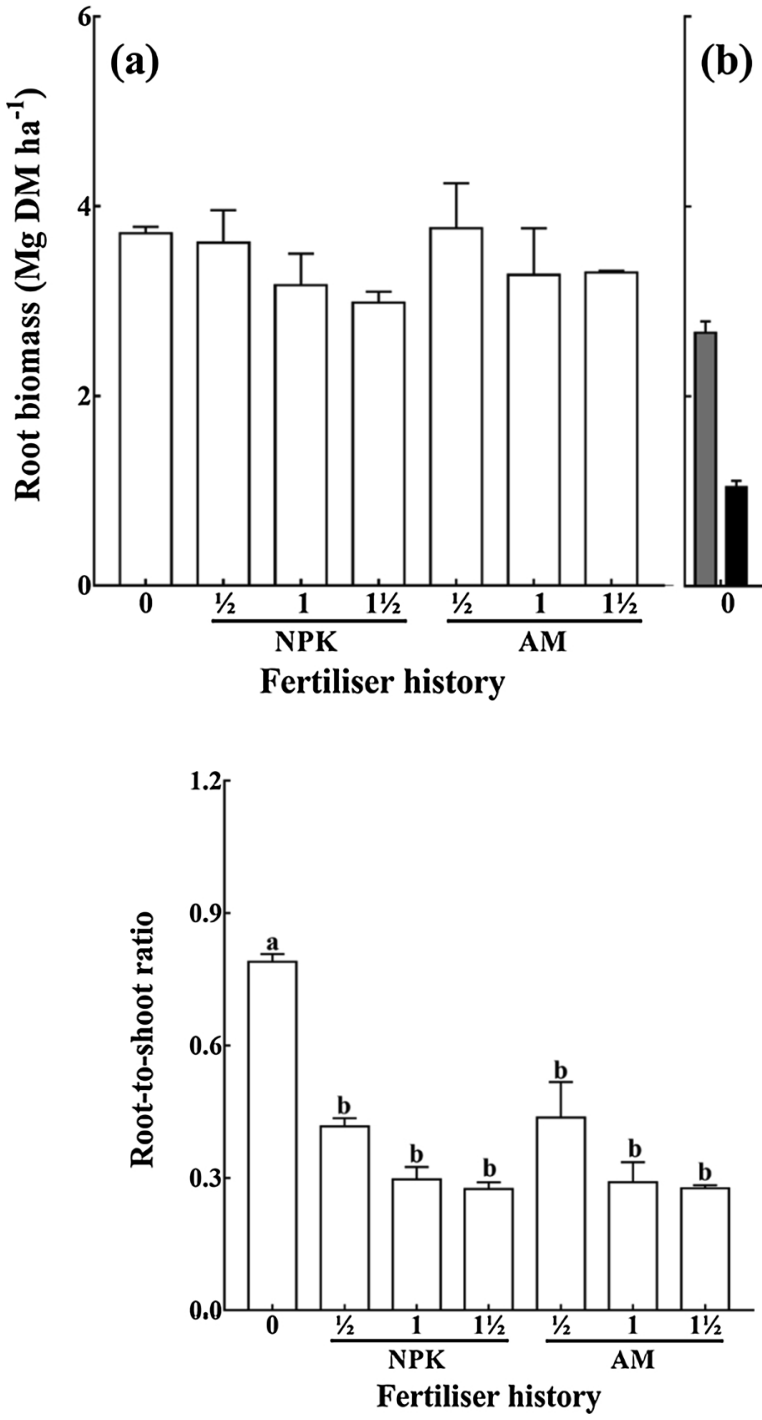

Fig. 4. Root-to-shoot ratio of grass-legume leys grown in soils with different fertiliser histories. Columns with error bars indicate means \pm 1 SE ( $n=2$ for $1 \frac{1}{2}$ NPK, $n=3$ for the other treatments). Columns with different lowercase letters indicate significant differences $(P<0.05)$ between fertiliser treatments using Tukey's post hoc test. Notably, the significance test was performed on logtransformed data to meet normality. Abbreviations for fertiliser treatments refer to Table 2 .

\section{Discussion}

We found that nutrient level affects herbage yield but not root biomass, leading to variations in $\mathrm{R} / \mathrm{S}$ ratios. The $\mathrm{R} / \mathrm{S}$ ratios decreased from deficient to sub-optimal nutrient level, but remained constant at levels above. The nutrient-dependent $\mathrm{R} / \mathrm{S}$ ratios were not affected by nutrient source. Instead, nutrient source altered herbage composition with higher grass proportion in soils receiving animal manure than those receiving mineral fertiliser.

\subsection{Nutrient level-dependent root-to-shoot ratios for estimating belowground $C$ input}

To simulate long-term changes in soil organic C stocks in grasslands, reliable estimates of belowground plant C inputs are required. Usually, these estimates are based on allometric functions that allocate a constant fraction of the harvested biomass to belowground $\mathrm{C}$ input (Bolinder et al., 2007). However, recent work has shown that this
Fig. 3. Root biomass (corrected to an ash-free basis) up to $20 \mathrm{~cm}$ soil depth (a, whole-plot root biomass; b, root biomass on rows and between rows) of grass-legume leys grown in soils with different fertiliser histories. Columns with error bars indicate means $\pm 1 \mathrm{SE}(n=2$ for $1 \frac{1}{2}$ NPK, $n=3$ for the other treatments). There was no significant difference $(P=$ 0.739) between treatments. Abbreviations for fertiliser treatments refer to Table 2 . approach may overestimate belowground C inputs for technologies that improve crop yields. Taghizadeh-Toosi et al. (2016) reported that the measured soil organic $\mathrm{C}$ did not change significantly despite improved wheat yield production, and Keel et al. (2017) found that using various allometric equations and associated coefficients led to large uncertainty in annual plant $\mathrm{C}$ inputs and hence changes in soil C stocks. The variations in plant $\mathrm{C}$ inputs depended on crop types. The largest difference (up to $6.6 \mathrm{Mg} \mathrm{Cha}^{-1}$ year $^{-1}$ ) was found for grass leys while differences between different approaches were smaller for cereals. These results suggest that using a fixed allometric equation (e.g. R/S ratio) for estimating belowground $\mathrm{C}$ input is inappropriate.

Recent work suggests that estimates of belowground C inputs or root biomass should adopt fixed $\mathrm{C}$ inputs based on crop species and farming system (Hu et al., 2018; Taghizadeh-Toosi et al., 2016). For example, Hu et al. (2018) showed that fixed values (e.g. 2.43 and $1.93 \mathrm{Mg} \mathrm{ha}^{-1}$ for wheat and barley grown in organic farming systems) gave a better prediction of root biomass than yield-dependent allometric functions. In line with these studies on cereals, we found that root biomass in the multispecies grass-legume ley remains constant irrespective of soil nutrient levels. Yet, the use of fixed values for belowground C input may be constrained by lack of site-relevant estimates of root biomass. Another approach is to apply an optimised R/S ratio adjusted for environmental factors. Poeplau (2016) showed that the optimised R/S ratio, estimated by using the RothC model and time series of soil $\mathrm{C}$ stocks in 15 temperate permanent grasslands, depends on $\mathrm{N}$ fertiliser levels $(5.9 \pm 1.9$ for unfertilised soils and $2.4 \pm 1.5$ for fertilised soils). We found that the R/S ratio of the grass-legume ley decreased from deficient to sub-optimal nutrient levels but remained constant above. Following the approach by Bolinder et al. (2007), we estimated root biomass input in soils with different fertiliser histories using fixed $\mathrm{R} / \mathrm{S}$ ratios. We found that the largest difference between treatments was $6.1 \mathrm{Mg} \mathrm{C}$ ha $^{-1}$ when using the maximum $\mathrm{R} / \mathrm{S}$ ratio (0.790) from unfertilized soils, while the difference was up to $2.3 \mathrm{Mg} \mathrm{C}$ ha ${ }^{-1}$ when using the minimum R/S ratio (0.277) from the soils with $1 \frac{1 / 2}{2} \mathrm{AM}$ (Table S1). Thus, using a constant R/S ratio will lead to erroneous estimates of root biomass when nutrient deficiency restricts plant growth in some agroecosystems, such as in organic farming and subsidised farming. We propose that nutrient level-dependent $\mathrm{R} / \mathrm{S}$ ratios estimate belowground $\mathrm{C}$ inputs more reliably than fixed allometric functions and are applicable when site-relevant root biomass observations are unavailable.

Previous studies demonstrate that root biomass and R/S ratios in forage grasslands vary with sampling depth (Jackson et al., 1996), grassland age (Acharya et al., 2012; Bolinder et al., 2002) and species diversity (Fan et al., 2008). Bolinder et al. (2007) reviewed 168 field measurements conducted in Canada and USA, and showed that the R/S 


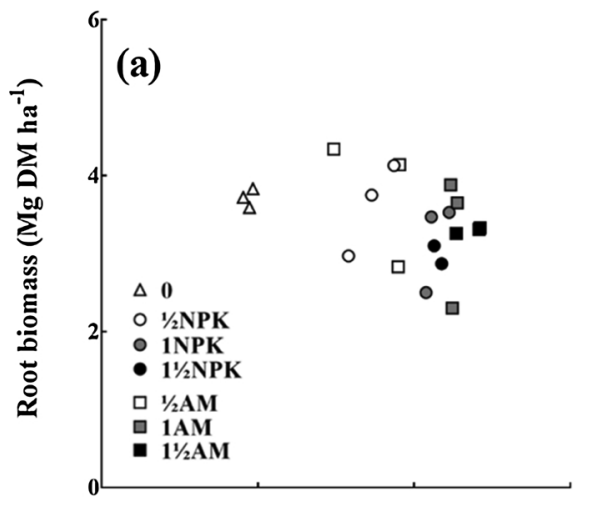

(b)
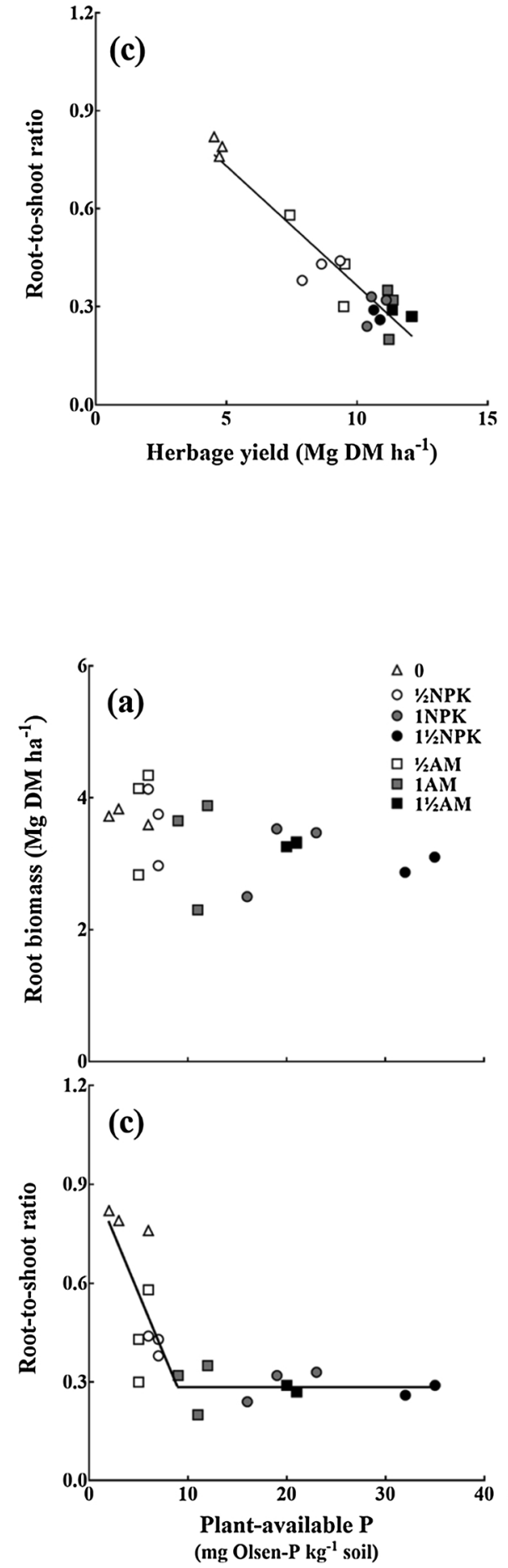

Fig. 5. The responses of ash-free root biomass (a, b) and rootto-shoot ratio (c, d) to plant parameters ( $a, c$, annual herbage yield; b, d, grass-to-legume ratio of herbage yield. Significant linear correlation between root-to-shoot ratio and annual herbage yield was observed (Panel c, $r^{2}=0.890, P<$ 0.001). Abbreviations for fertiliser treatments refer to Table 2 .

\section{(d)}
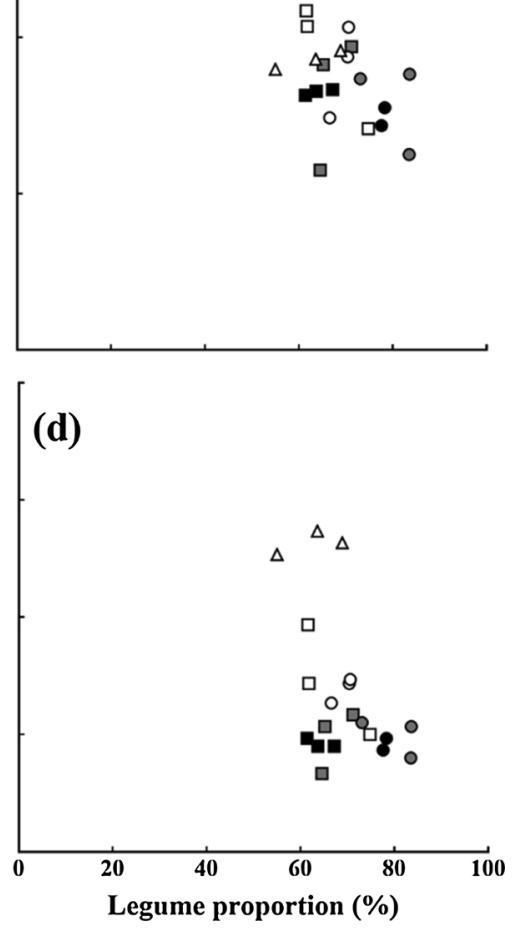

Fig. 6. The responses of ash-free root biomass (a, b) and rootto-shoot ratio (c, d) to soil nutrient availability (a, c, plantavailable P; b, d, plant-available K). The broken-stick model was used to identify the threshold values, which were $8.75 \mathrm{mg}$ Olsen-P kg${ }^{-1}$ soil (Panel c, $r^{2}=0.702, P<0.001$ ) and $48.7 \mathrm{mg} \mathrm{NH}_{4} \mathrm{OAc}-\mathrm{K} \mathrm{kg}{ }^{-1}$ soil (Panel d, $r^{2}=0.816$, $P<0.001$ ), respectively. Abbreviations for fertiliser treatments refer to Table 2 .

(d)

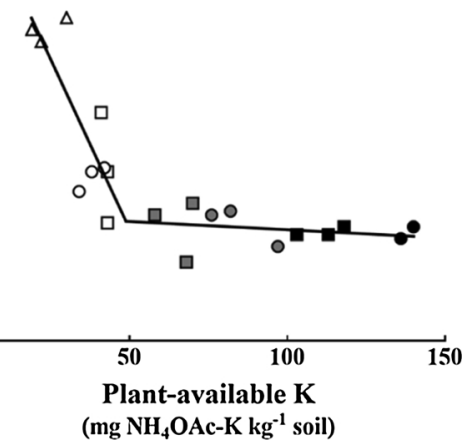


ratio in grasslands ranged widely (from 0.1 to 5.0 ; mean value of 1.6). In our study, R/S ratios decreased from 0.93 (unfertilised) to $0.48(1 / 2$ standard rate) and remained at $0.33-0.34$ at higher nutrient levels (1 and $1 \frac{1 / 2}{2}$ rate). Our values are at the lower end of the range reported by Bolinder et al. (2007). This may partly be ascribed to the young age of the ley (1st production year) and/or the shallow sampling of roots (0-20 cm soil depth) applied in our study. Bolinder et al. (2002) showed that root biomass in grasslands increased by $50 \%$ from the 1 st to the 2nd production year with almost $90 \%$ of all roots present in $0-30 \mathrm{~cm}$ soil depth. Cougnon et al. (2017) examined root biomass of five common European forage grass species and found that less than $10 \%$ of total root biomass was present below $30 \mathrm{~cm}$ depth and that $\mathrm{N}$ fertilisation did not affect root biomass at deeper soil layers between species.

We did not measure fine root turnover and rhizodeposition in this study. It has been indicated that these two sources of belowground $\mathrm{C}$ inputs may have significant impacts on crop productivity and long-term soil fertility (Gill and Jackson, 2000). Recent studies have shown that fast-growing grass species (e.g. ryegrass) and legume species (e.g. lucerne) may have high rhizodeposition and root turnover rate (Reid and Crush, 2013; Reid et al., 2015). The rate was found to increase in nutrient-rich soils (Van der Krift et al., 2001; Van der Krift and Berendse, 2002). These results suggest that fine root turnover and rhizodeposition of grass-legume leys may increase with increasing soil nutrient availability, which requires further investigation.

The grassland leys were dominated by legume species and thus $\mathrm{N}$ was expected not to be a main limiting factor. Threshold values for plant available $\mathrm{P}$ and $\mathrm{K}$ were $8.75 \mathrm{mg}$ Olsen- $\mathrm{P} \mathrm{kg}^{-1}$ soil and $48.7 \mathrm{mg}$ $\mathrm{NH}_{4} \mathrm{OAc}-\mathrm{K} \mathrm{kg}^{-1}$ soil, respectively (Fig. 6). These values are low according to recommendations for plant nutrition (Cooper et al., 2018; $\emptyset$ gaard et al., 2002), and it is recalled that the grass-legume ley remained unfertilised in the production year. Herbage yields decreased significantly in plots with a fertiliser history from 1 to $\frac{1}{2}$ rate (Fig. 1), suggesting that yields were limited by both $\mathrm{P}$ and $\mathrm{K}$.

\subsection{Nutrient source modified herbage composition but not root biomass}

Previous studies demonstrate a higher abundance of grasses in plots receiving $\mathrm{N}$ fertiliser, while legumes dominate in plots receiving only $\mathrm{P}$ and K (e.g. the Park Grass Experiment, Silvertown et al., 2006). We found that soils with a history of mineral fertiliser (1 NPK and 1 1/2 NPK) had higher $\mathrm{P}$ and $\mathrm{K}$ availability than soils with equivalent addition of $\mathrm{P}$ and $\mathrm{K}$ in animal manure (Table 2). Compared with application of mineral $\mathrm{N}$ fertiliser, long-term application of $\mathrm{N}$ with animal manure leads to soil with a higher $\mathrm{N}$ mineralization potential derived from the turnover of accumulated manure residues (Petersen et al., 2010; Suarez-Tapia et al., 2018). Higher P and K, and lower N availability may explain the higher proportion of legumes observed on plots with a history of mineral fertiliser (i.e. 1 NPK and 11/2 NPK, Fig. 2).

In agroecosystems, organic fertiliser such as animal manure may either enhance or maintain root biomass of arable crops and catch crops compared to mineral fertiliser (Chirinda et al., 2012; Hu et al., 2018). However, the effect of nutrient source (organic vs. mineral) on root biomass remains obscure in multispecies grasslands. Animal manure enhanced herbage yield of grasses compared to mineral fertiliser (Fig. 2a). Given that grasses showed a higher R/S ratio than legumes (Fornara and Tilman, 2008), we expected higher total root biomass in soils with a history of animal manure than in soils previously supplied with mineral fertiliser. Yet, our results showed that root biomass and R/ $S$ ratio were unaffected by nutrient source (Figs. 3 and 4). This aligns with a recent study by Głab and Kacorzyk (2011) that showed no difference in root biomass, root length density and $R / S$ ratio between manure and mineral fertiliser in a multispecies meadow grassland. These results indicate that nutrient source may affect the R/S ratio of grasses and legumes differently. This could be unravelled by using DNA analyses (Mommer et al., 2010) of mixed root samples to disentangle the abundance of root biomass of individual species. We conclude that nutrient source (organic vs. mineral) affects aboveground plant community composition but not the overall belowground biomass allocation of grass-legume leys.

\subsection{Herbage yield rather than composition affected root-to-shoot ratio}

We found that root biomass was independent of herbage yield in grass-legume leys (Fig. 5a) and that the R/S ratio decreased linearly with increasing herbage yield (Fig. 5c). This emphasizes that using a fixed R/S ratio will overestimate belowground $\mathrm{C}$ input for management practices that improve herbage yield. Our results showed that increased above ground biomass with increasing soil nutrient availability can be achieved with the same root biomass, suggesting that other root traits (such as root morphology and physiology) may be more important than root biomass for nutrient uptake. Recent studies showed that fastgrowing species (e.g. ryegrass) had higher root length density and physiological nutrient-uptake capacities in nutrient-rich environment than nutrient-poor one, but root biomass hardly changed (Fransen et al., 1998; Hodge, 2004).

Neither root biomass nor R/S ratio correlated with the legume or grass proportion of herbage yield (Fig. 5b, d). This indicates that at the plant community level, aboveground plant productivity rather than species composition controls the allocation of biomass between aboveground and belowground. Future work may reveal whether these patterns, observed for temperate leys, are valid for other climatic conditions, soil types and other plant communities (Nguyen, 2009; Palta and Gregory, 1997).

\subsection{Conclusions}

We conclude that soil nutrient levels, established from different fertiliser histories, defines herbage yield but not root biomass, leading to varying $\mathrm{R} / \mathrm{S}$ ratios. The $\mathrm{R} / \mathrm{S}$ ratio decreased from deficient to suboptimal nutrient level, but remained constant at levels above. The nutrient level-dependent $\mathrm{R} / \mathrm{S}$ ratios will provide a more reliable estimate of belowground biomass input in multispecies leys and contribute to better predictions of long-term soil C storage of temperate grasslands subject to different nutrient managements. In addition, aboveground plant productivity rather than plant community composition defines root biomass and $\mathrm{R} / \mathrm{S}$ ratio.

\section{Declarations of interest}

None.

\section{Acknowledgements}

This study was financially supported by the Green Development and Demonstration Program 'MultiPlant project' [grant number 34009-130678] and coordinated by the International Centre for Research in Organic Food Systems (ICROFS). We gratefully acknowledge the excellent technical assistance provided by the technical staff at Askov Experimental Station.

\section{Appendix A. Supplementary data}

Supplementary material related to this article can be found, in the online version, at doi:https://doi.org/10.1016/j.agee.2019.02.014.

\section{References}

Acharya, B.S., Rasmussen, J., Eriksen, J., 2012. Grassland carbon sequestration and emissions following cultivation in a mixed crop rotation. Agric. Ecosyst. Environ. 153, 33-39.

Anderson, J.M., 1991. The effects of climate change on decomposition processes in grassland and coniferous forests. Ecol. Appl. 1, 326-347.

Bolinder, M.A., Angers, D.A., Bélanger, G., Michaud, R., Laverdière, M.R., 2002. Root 
biomass and shoot to root ratios of perennial forage crops in eastern Canada. Can. J. Plant Sci. 82, 731-737.

Bolinder, M.A., Janzen, H.H., Gregorich, E.G., Angers, D.A., VandenBygaart, A.J., 2007. An approach for estimating net primary productivity and annual carbon inputs to soil for common agricultural crops in Canada. Agric. Ecosyst. Environ. 118, 29-42.

Chirinda, N., Olesen, J.E., Porter, J.R., 2012. Root carbon input in organic and inorganic fertilizer-based systems. Plant Soil. 359, 321-333.

Christensen, B.T., Petersen, J., Trentemøller, U.M., 2006. The Askov Long-Term Experiments on Animal Manure and Mineral Fertilizers: The Lermarken Site 1894-2004. DIAS Report Plant Production No. 121. Danish Institute of Agricultural Sciences, Tjele, Denmark.

Coleman, K., Jenkinson, D.S., Crocker, G.J., Grace, P.R., Klír, J., Körschens, M., Poulton, P.R., Richter, D.D., 1997. Simulating trends in soil organic carbon in long-term experiments using RothC-26.3. Geoderma 81, 29-44.

Cong, W.-F., Jing, J., Rasmussen, J., Søegaard, K., Eriksen, J., 2017. Forbs enhance productivity of unfertilised grass-clover leys and support low-carbon bioenergy. Sci. Rep. 7, 1422.

Cooper, J., Reed, E.Y., Hörtenhuber, S., Lindenthal, T., Løes, A.-K., Mäder, P., Magid, J., Oberson, A., Kolbe, H., Möller, K., 2018. Phosphorus availability on many organically managed farms in Europe. Nutr. Cycl. Agroecosyst. 110, 227-239.

Cougnon, M., De Swaef, T., Lootens, P., Baert, J., De Frenne, P., Shahidi, R., Roldán-Ruiz, I., Reheul, D., 2017. In situ quantification of forage grass root biomass, distribution and diameter classes under two N fertilisation rates. Plant Soil. 411, 409-422.

De Groot, C.C., Marcelis, L.F.M., Van Den Boogaard, R., Lambers, H., 2001. Growth and dry-mass partitioning in tomato as affected by phosphorus nutrition and light. Plant Cell Environ. 24, 1309-1317.

do Rosário, G., Oliveira, M., van Noordwijk, M., Gaze, S.R., Brouwer, G., Bona, S., Mosca, G., Hairiah, K., 2000. Auger sampling, ingrowth cores and pinboard methods. In: Smit, A.L., Bengough, A.G., Engels, C., van Noordwijk, M., Pellerin, S., van de Geijn, S.C. (Eds.), Root Methods: A Handbook. Berlin, Heidelberg. Springer, Berlin Heidelberg, pp. 175-210.

Fan, F., Zhang, F., Qu, Z., Lu, Y., 2008. Plant carbon partitioning below ground in the presence of different neighboring species. Soil Biol Biochem. 40, 2266-2272.

Field, C.B., 1991. Ecological scaling of carbon gain to stress and resource availability. In: Mooney, H.A., Winner, W.E., Pell, E.J. (Eds.), Response of Plants to Multiple Stresses. Academic Press, New York, USA, pp. 35-65.

Fornara, D.A., Tilman, D., 2008. Plant functional composition influences rates of soil carbon and nitrogen accumulation. J. Ecol. 96, 314-322.

Fransen, B., de Kroon, H., Berendse, F., 1998. Root morphological plasticity and nutrient acquisition of perennial grass species from habitats of different nutrient availability. Oecologia 115, 351-358.

Friedlingstein, P., Joel, G., Field, C.B., Fung, I.Y., 1999. Toward an allocation scheme for global terrestrial carbon models. Glob. Change Biol. 5, 755-770.

Gill, R.A., Jackson, R.B., 2000. Global patterns of root turnover for terrestrial ecosystems. New Phytol. 147, 13-31.

Głab, T., Kacorzyk, P., 2011. Root distribution and herbage production under different management regimes of mountain grassland. Soil Tillage Res. 113, 99-104.

Grime, J.P., 2002. Plant Strategies, Vegetation Processes, and Ecosystem Properties, second edition. Wiley, Hoboken.

Hodge, A., 2004. The plastic plant: root responses to heterogeneous supplies of nutrients. New Phytol. 162, 9-24.

Hu, T., Sørensen, P., Wahlström, E.M., Chirinda, N., Sharif, B., Li, X., Olesen, J.E., 2018. Root biomass in cereals, catch crops and weeds can be reliably estimated without considering aboveground biomass. Agric. Ecosyst. Environ. 251, 141-148.

IPCC, 2014. Climate change 2014, synthesis report. In: Pachauri, R.K., Meyer, L.A. (Eds.), Contribution of Working Groups I, II and III to the Fifth Assessment Report of the Intergovernmental Panel on Climate Change, Core Writing Team. IPCC, Geneva, Switzerland, pp. 1-112.

Iwasa, Y., Roughgarden, J., 1984. Shoot/root balance of plants: optimal growth of a system with many vegetative organs. Theor. Popul. Biol. 25, 78-105.

Jackson, R.B., Canadell, J., Ehleringer, J.R., Mooney, H.A., Sala, O.E., Schulze, E.D., 1996. A global analysis of root distributions for terrestrial biomes. Oecologia 108, 389-411.

Keel, S.G., Leifeld, J., Mayer, J., Taghizadeh-Toosi, A., Olesen, J.E., 2017. Large uncertainty in soil carbon modelling related to method of calculation of plant carbon input in agricultural systems. Eur. J. Soil Sci. 68, 953-963.

Lal, R., 2004. Soil carbon sequestration impacts on global climate change and food security. Science 304, 1623-1627.

Mommer, L., van Ruijven, J., de Caluwe, H., Smit-Tiekstra, A.E., Wagemaker, C.A.M., Ouborg, N.J., Bögemann, G.M., van der Weerden, G.M., Berendse, F., de Kroon, H., 2010. Unveiling below-ground species abundance in a biodiversity experiment: a test of vertical niche differentiation among grassland species. J. Ecol. 98, 1117-1127.

Nguyen, C., 2009. Rhizodeposition of organic C by plant: mechanisms and controls. In: Lichtfouse, E., Navarrete, M., Debaeke, P., Véronique, S., Alberola, C. (Eds.), Sustainable Agriculture. Springer, Dordrecht, pp. 97-123.

$\emptyset$ gaard, A.F., Krogstad, T., Lunnan, T., 2002. Ability of some Norwegian soils to supply grass with potassium (K) - soil analyses as predictors of K supply from soil. Soil Use Manage. 18, 412-420.

Palta, J.A., Gregory, P.J., 1997. Drought affects the fluxes of carbon to roots and soil in ${ }^{13} \mathrm{C}$ pulse-labelled plants of wheat. Soil Biol Biochem. 29, 1395-1403.

Peltre, C., Nyord, T., Christensen, B.T., Jensen, J.L., Thomsen, I.K., Munkholm, L.J., 2016. Seasonal differences in tillage draught on a sandy loam soil with long-term additions of animal manure and mineral fertilizers. Soil Use Manage. 32, 583-593.

Petersen, J., Thomsen, I.K., Mattsson, L., Hansen, E.M., Christensen, B.T., 2010. Grain yield and crop $\mathrm{N}$ offtake in response to residual fertilizer $\mathrm{N}$ in long-term field experiments. Soil Use Manage. 26, 455-464.

Poeplau, C., 2016. Estimating root: shoot ratio and soil carbon inputs in temperate grasslands with the RothC model. Plant Soil. 407, 293-305.

Poorter, H., Nagel, O., 2000. The role of biomass allocation in the growth response of plants to different levels of light, $\mathrm{CO}_{2}$, nutrients and water: a quantitative review. Aust. J. Plant Physiol. 27, 1191.

Poorter, H., Niklas, K.J., Reich, P.B., Oleksyn, J., Poot, P., Mommer, L., 2012. Biomass allocation to leaves, stems and roots: meta-analyses of interspecific variation and environmental control. New Phytol. 193, 30-50.

R Core Team, 2013. R: A Language and Environment for Statistical Computing. R Foundation for Statistical Computing, Vienna, Austria.

Reich, P.B., Buschena, C., Tjoelker, M.G., Wrage, K., Knops, J., Tilman, D., Machado, J.L., 2003. Variation in growth rate and ecophysiology among 34 grassland and savanna species under contrasting $\mathrm{N}$ supply: a test of functional group differences. New Phytol. 157, 617-631.

Reid, J.B., Crush, J.R., 2013. Root turnover in pasture species: perennial ryegrass (lolium perenne L.). Crop Pasture Sci. 64, 165-177.

Reid, J.B., Gray, R.A.J., Springett, J.A., Crush, J.R., 2015. Root turnover in pasture species: chicory, lucerne, perennial ryegrass and white clover. Ann Appl. Biol. 167, 327-342.

Silvertown, J., Poulton, P., Johnston, E., Edwards, G., Heard, M., Biss, P.M., 2006. The park grass experiment 1856-2006: its contribution to ecology. J. Ecol. 94, 801-814.

Suarez-Tapia, A., Thomsen, I.K., Rasmussen, J., Christensen, B.T., 2018. Residual N effect of long-term applications of cattle slurry using winter wheat as test crop. Field Crops Res. 221, 257-264.

Taghizadeh-Toosi, A., Christensen, B.T., Hutchings, N.J., Vejlin, J., Kätterer, T., Glendining, M., Olesen, J.E., 2014. C-TOOL: a simple model for simulating wholeprofile carbon storage in temperate agricultural soils. Ecol. Model. 292, 11-25.

Taghizadeh-Toosi, A., Christensen, B.T., Glendining, M., Olesen, J.E., 2016. Consolidating soil carbon turnover models by improved estimates of belowground carbon input. Sci. Rep. 6, 32568 .

Tilman, D., 1988. Plant Strategies and the Dynamics and Structure of Plant Communities. Princeton University Press, Princeton.

Toms, J.D., Lesperance, M.L., 2003. Piecewise regression: a tool for identifying ecological thresholds. Ecology 84, 2034-2041.

Van der Krift, T.A., Berendse, F., 2002. Root life spans of four grass species from habitats differing in nutrient availability. Funct Ecol. 16, 198-203.

Van der Krift, T.A., Kuikman, P.J., Möller, F., Berendse, F., 2001. Plant species and nutritional-mediated control over rhizodeposition and root decomposition. Plant Soil. 228, 191-200.

Xia, J., Wan, S., 2008. Global response patterns of terrestrial plant species to nitrogen addition. New Phytol. 179, 428-439. 